\title{
ROLE OF HEAT LABILE ANTIGENS OF SHIGELLA FLEXNERI IN HELA CELL INVASION
}

\author{
Smita R. Bhogale, K. D. Sharma and R. S. Kamat \\ Department of Clinical Pathology, Haffkine Institute, Parel, Bombay 400012, India
}

\begin{abstract}
SUMmARY. In studies of the role of surface antigens of Shigella flexneri in HeLa cell invasion, three antisera were employed to block the invasion. Antisera against live (ALS) and boiled (ABS) S. flexneri blocked invasion very effectively. Reduction in the numbers of intracellular shigellae was always accompanied by reduction in the number adherent to the cells, indicating the importance of adhesion in the invasive process. Anti-live absorbed antiserum (ALAS) prepared by exhaustive absorption of ALS with boiled $S$. flexneri blocked adhesion and invasion at dilutions of 20 or 50 ; the efficiency of the absorption was indicated by absence of agglutinating and anti-lipopolysaccharide (LPS) antibodies. S. flexneri LPS did not block adhesion and invasion even at a concentration of $1.0 \mathrm{mg} / \mathrm{ml}$. Hence it was concluded that heat-labile surface antigens are important in adhesion and invasion of HeLa cells by $S$. flexneri. Antiserum against heat stable antigen (ABS) probably blocks adhesion by steric hindrance.
\end{abstract}

\section{INTRODUCTION}

Epithelial cell invasion by virulent shigellae is an important step in the pathogenesis of bacillary dysentery (LaBrec et al., 1964). Though the process of internalisation of the shigellae into the epithelial cell has been referred to as invasion, it appears to be due to active endocytosis by the epithelial cell (Hale, Morris and Bonventre, 1979). In this paper, we report studies on antigenic interactions between the shigellae and the epithelial cell occurring prior to invasion.

\section{MATERIAL AND METHODS}

Bacterial strain. A strain of Shigella flexneri isolated from a case of bacillary dysentery was used. Since shigellae are known to lose invasiveness after repeated passage on artificial media (Mackel, Langley and Venice, 1961; Okamura and Nakaya, 1977), the strain was lyophilised immediately after isolation and identification. The lyophilised culture was stored at $4{ }^{\circ} \mathrm{C}$. On each test occasion the HeLa cell invasion assay was performed with a freshly revived culture, so that results would be comparable. A laboratory isolate of Escherichia coli was used as a control organism.

Source and maintenance of $\mathrm{HeLa}$ cell line. The HeLa cell line was obtained from the National Institute of Virology, Pune, India. The cell cultures were maintained routinely as monolayers in Dulbecco's modified Eagle's medium with newborn calf serum $15 \%$, penicillin G $100 \mathrm{U} / \mathrm{ml}$, streptomycin $100 \mu \mathrm{g} / \mathrm{ml}$ and amphotericin B $2 \cdot 5 \mu \mathrm{g} / \mathrm{ml}$. 
Antisera. Hyperimmune rabbit antisera were raised as described by Edwards and Ewing (1972). Rabbits received intravenously (i.v.) $0.5,1.0,2.0$ and $3.0 \mathrm{ml}$ of an appropriate suspension of $S$. flexneri at intervals of 3-4 days and were bled 1 week after the last injection.

Anti-live $S$. flexneri antiserum $(A L S)$ was prepared by immunisation with live cells of $S$. flexneri. Because these were quite toxic to rabbits, two additional initial immunisations were given with $0.25 \mathrm{ml}$ of a suspension containing $10^{9}$ organisms $/ \mathrm{ml}$ of formalinised S. flexneri.

Anti-boiled $S$. flexneri antiserum $(A B S)$ was raised by immunisation with a suspension of boiled cells of $S$. flexneri $\left(10^{9} / \mathrm{ml}\right)$ prepared as described by Edwards and Ewing (1972).

Anti-live S. flexneri absorbed antiserum ( $A L A S)$ was ALS absorbed with washed and boiled cells of $S$. flexneri until all anti-LPS activity was absorbed.

Assay of antibody activity. Whole bacterial cell agglutination titre was determined with a suspension of boiled S. flexneri, by the method of Williams and Chase (1977). Anti-LPS titre was determined by microtitre passive haemagglutination of sheep red cells sensitised with $S$. flexneri LPS as described by Kwapinski (1972).

HeLa cell invasion assay. A modified assay of $\mathrm{LaBrec}$ et al. (1964) was done with confluent monolayers in $35 \mathrm{~mm}$ disposable plastic petri dishes incubated at $37^{\circ} \mathrm{C}$ in air $+\mathrm{CO}_{2} 5 \%$ in a humidified chamber: $3 \mathrm{~h}$ before the assay, the culture medium containing antibiotics was replaced with $2 \mathrm{ml}$ of antibiotic-free Dulbecco's medium and incubation was continued for $3 \mathrm{~h}$. Then the medium was replaced by $1 \mathrm{ml}$ of Dulbecco's medium containing the requisite number of shigellae. A volume of the bacterial inoculum was diluted and plated out to compute the number of viable organisms deposited on the monolayers. The challenged monolayers were further incubated as before for $3 \mathrm{~h}$ and then washed six times with $0.15 \mathrm{~m}$ phosphate-buffered saline (PBS) at pH 7.2. To one set of monolayers, Dulbecco's medium containing gentamicin $50 \mu \mathrm{g} / \mathrm{ml}$ was added to kill extracellular bacteria. A parallel set was given Dulbecco's medium without any antibiotic, to provide an estimate of adherent extracellular bacteria along with intracellular bacteria. After incubation for $6 \mathrm{~h}$ at $37^{\circ} \mathrm{C}$, the monolayers were treated with trypsin $0.25 \%$ in Hanks' balanced salt solution (BSS). The cell suspensions were transferred to siliconised centrifuge tubes, and washed three times with Hanks' BSS containing gelatin $0.1 \%$. After the last wash, the cell pellet was suspended in distilled water containing bovine serum albumin $0.1 \%$. It was rapidly freeze-thawed three times to lyse the cells and to liberate intracellular bacteria. The lysate was then diluted and plated out to compute the viable bacteria by counting colony forming units (cfu).

Statistical analysis. The data were analysed by the Student $t$ test (Bancroft, 1957).

\section{RESULTS}

\section{Characterisation of the antisera}

The whole cell agglutination and anti-LPS titres of the three antisera are shown in table I. The anti-LPS titre of the serum prepared against boiled bacteria (ABS) was

TABLE I

Details of the antisera used

\begin{tabular}{|c|c|c|}
\hline \multicolumn{3}{|c|}{$\begin{array}{l}\text { Whole cell } \\
\text { agglutination Anti-LPS }\end{array}$} \\
\hline Antiserum* & titre & titre \\
\hline ALS & 320 & 1024 \\
\hline ABS & 320 & 20480 \\
\hline ALAS & nil & nil \\
\hline
\end{tabular}

* See Methods. 
TABLE II

Results of a representative experiment with the HeLa cell invasion assay

\begin{tabular}{|c|c|c|}
\hline \multirow[b]{2}{*}{$\begin{array}{c}\text { Challenge } \\
\text { organism } \\
\text { (109/monolayer) }\end{array}$} & \multicolumn{2}{|c|}{ Mean count* (cfu/plate) of } \\
\hline & $\begin{array}{l}\text { intracellular } \\
\text { organisms } \dagger\end{array}$ & $\begin{array}{l}\text { total intracellular } \\
\text { and extracellular } \\
\text { organisms }\end{array}$ \\
\hline $\begin{array}{l}\text { Shigella flexneri } \\
\text { Escherichia coli }\end{array}$ & $\begin{array}{c}1.65( \pm 0.176) \times 10^{6} \\
4.07( \pm 0.01) \times 10^{3}\end{array}$ & $\begin{array}{l}9.0( \pm 0.132) \times 10^{6} \\
5.73( \pm 0.63) \times 10^{8}\end{array}$ \\
\hline
\end{tabular}

* \pm Standard error of the mean.

$+\mathrm{cfu} /$ monolayer in the presence of gentamicin.

$\ddagger \mathrm{cfu} /$ monolayer in medium without gentamicin.

much higher than that of the anti-live serum (ALS). The anti-live absorbed serum (ALAS) was free of agglutinating and anti-LPS antibodies.

\section{Quantitative aspects of HeLa cell invasion assay}

Results of a representative experiment are shown in table II. Confluent HeLa cell monolayers in $35 \mathrm{~mm}$ plastic petri dishes were incubated with $10^{9}$ cells of $S$. flexneri. After $3 \mathrm{~h}$ the plates were washed with PBS and two parallel sets of monolayers were established (see Methods).

The mean bacterial count per plate in the presence of gentamicin was $1.65 \times 10^{6}$. This number is an estimate of the intracellular bacteria since gentamicin cannot penetrate the live HeLa cells. The mean bacterial count per plate in the absence of gentamicin was $9.0 \times 10^{6}$ and this indicates the total number of intracellular and extracellular adherent shigellae. It is clear that more than $80 \%$ of the shigellae were extracellular and adherent to the monolayers and could not be dislodged by washing. However, it is significant that as many as $18.3 \%$ of the shigellae were intracellular. Strains of normal colonic Escherichia coli when similarly tested on HeLa cell monolayers yielded negligible numbers of organisms in the presence of gentamicin. Results of one representative experiment are shown (table II) in which only $0.0007 \%$ of the total $E$. coli organisms survived on the monolayers in the presence of gentamicin. The difference between the estimates for intracellular shigellae and $E$. coli was highly significant $(\mathrm{p}<0.005)$.

\section{Blockade of adhesion and invasion by the antisera}

HeLa cell monolayers were incubated with $c .10^{7}$ cells of $S$. flexneri suspended in $2 \cdot 0$ $\mathrm{ml}$ of Dulbecco's medium containing heat-inactivated antisera or normal rabbit serum (NRS). The results given in table III show that ALS and ABS reduced the number of intracellular organisms by c. $31-89 \%$ at a dilution of 200 . The total numbers of organisms, i.e. both intracellular and extracellular adherent organisms, were also reduced in the presence of the two antisera by c. $46-89 \%$. Since $>90 \%$ of the total 
TABLE III

Effect of the test antisera on adhesion and invasion of HeLa cells by $\mathrm{S}$. flexneri

\begin{tabular}{|c|c|c|c|c|c|c|}
\hline \multirow[b]{2}{*}{$\begin{array}{l}\text { Test } \\
\text { no. }\end{array}$} & \multirow[b]{2}{*}{$\begin{array}{c}\text { Inoculum per } \\
\text { monolayer }\left(10^{7}\right. \\
\text { organisms })\end{array}$} & \multirow[b]{2}{*}{$\begin{array}{l}\text { Serum } \\
\text { (and test } \\
\text { dilution) }\end{array}$} & \multicolumn{2}{|c|}{ Mean count* $\left(10^{6} \mathrm{cfu} /\right.$ plate $)$} & \multirow[b]{2}{*}{$\begin{array}{l}\text { Percentage } \\
\text { reduction of } \\
\text { intraceliular } \\
\text { organisms }\end{array}$} & \multirow[b]{2}{*}{$\begin{array}{l}\text { Percentage } \\
\text { inhibition } \\
\text { of adhesion }\end{array}$} \\
\hline & & & $\begin{array}{l}\text { intracellular } \\
\text { organisms }\end{array}$ & $\begin{array}{l}\text { total intra- } \\
\text { cellular and } \\
\text { extracellular } \\
\text { organisms }\end{array}$ & & \\
\hline 1 & 1.03 & $\begin{array}{l}\text { NRS } \\
(200) \\
\text { ALS } \\
(200)\end{array}$ & $\begin{array}{c}0.392( \pm 0.03) \\
0.165 \\
( \pm 0.003)\end{array}$ & $\begin{array}{c}8.8 \\
( \pm 0.09) \\
3.32 \\
( \pm 0.17)\end{array}$ & $57 \cdot 9$ & $62 \cdot 2$ \\
\hline 2 & 1.57 & $\begin{array}{l}\text { NRS } \\
(200) \\
\text { ALS } \\
(200)\end{array}$ & $\begin{array}{c}0.289 \\
( \pm 0.01) \\
0.031 \\
( \pm 0.001)\end{array}$ & $\begin{array}{c}7.58 \\
( \pm 0.19) \\
0.81 \\
( \pm 0.03)\end{array}$ & $89 \cdot 23$ & $89 \cdot 3$ \\
\hline 3 & 1.59 & $\begin{array}{l}\text { NRS } \\
(200) \\
\text { ABS } \\
(200)\end{array}$ & $\begin{array}{c}0.42 \\
( \pm 0.01) \\
0.293 \\
( \pm 0.01)\end{array}$ & $\begin{array}{c}9 \cdot 57 \\
( \pm 0 \cdot 1) \\
5 \cdot 13 \\
( \pm 0 \cdot 1)\end{array}$ & $31 \cdot 0$ & $46 \cdot 4$ \\
\hline 4 & 1.88 & $\begin{array}{c}\text { NRS } \\
(200) \\
\text { ALAS } \\
(200)\end{array}$ & $\begin{array}{l}\text { ND } \\
\text { ND }\end{array}$ & $\begin{array}{c}54 \cdot 7 \\
( \pm 0 \cdot 7) \\
51 \cdot 1 \\
( \pm 0 \cdot 6)\end{array}$ & $\cdots$ & $6 \cdot 5$ \\
\hline 5 & $1 \cdot 7$ & $\begin{array}{c}\text { NRS } \\
(50) \\
\text { ALAS } \\
(50)\end{array}$ & $\begin{array}{l}\text { ND } \\
\text { ND }\end{array}$ & $\begin{array}{c}51 \cdot 6 \\
( \pm 0 \cdot 19) \\
17 \cdot 6 \\
( \pm 0 \cdot 24)\end{array}$ & $\cdots$ & $65 \cdot 9$ \\
\hline 6 & $1 \cdot 1$ & $\begin{array}{c}\text { NRS } \\
(20) \\
\text { ALAS } \\
(20)\end{array}$ & $\begin{array}{c}1 \cdot 16 \\
( \pm 0.01) \\
0 \cdot 313 \\
( \pm 0.02)\end{array}$ & $\begin{array}{c}32 \cdot 3 \\
( \pm 0 \cdot 2) \\
8 \cdot 9 \\
( \pm 0 \cdot 07)\end{array}$ & $73 \cdot 0$ & $72 \cdot 0$ \\
\hline
\end{tabular}

$\mathrm{NRS}=$ Normal Rabbit Serum; ABS, ALS, ALAS-see Methods; ND= not done. * See table II.

organisms on the monolayers are extracellular adherent bacteria, the reduction in their numbers clearly indicates inhibition of adhesion of the shigellae to the monolayers by the two antisera. It could be argued that the observed effect was due to clumping of bacteria in the presence of the antisera. This can be ruled out because no bacterial agglutination was observed when $S$. flexneri were mixed at a concentration of $10^{7}$ cells $/ \mathrm{ml}$ with the antisera at a dilution of 200 .

The ALAS did not block adhesion to the monolayers at a dilution of 200 but did so at dilutions of 50 and 20 (table III). Its ability to reduce the numbers of intracellular shigellae was also tested and confirmed (table III). The results were significant, $p$ values ranging from $<0.05$ to $<0.005$.

\section{Effect of inoculum size on inhibition of adhesion and invasion by ABS and ALS}

A series of HeLa cell monolayers were incubated in the presence of heat-inactivated ABS and ALS at a dilution of 200 with graded numbers of $S$. flexneri. The antisera 
TABLE IV

Relationship between inoculum size and blockade of adhesion and invasion by ALS and ABS

\begin{tabular}{|c|c|c|c|c|c|c|}
\hline \multirow[b]{2}{*}{$\begin{array}{l}\text { Test } \\
\text { no. }\end{array}$} & \multirow[b]{2}{*}{$\begin{array}{l}\text { Inoculum } \\
\text { per } \\
\text { monolayer }\end{array}$} & \multirow[b]{2}{*}{$\begin{array}{l}\text { Serum } \\
\text { (and test } \\
\text { dilution) }\end{array}$} & \multicolumn{2}{|c|}{ Mean count ${ }^{*}\left(10^{6} \mathrm{cfu} / \mathrm{plate}\right)$} & \multirow[b]{2}{*}{$\begin{array}{l}\text { Percentage } \\
\text { reduction in } \\
\text { intracellular } \\
\text { organisms }\end{array}$} & \multirow[b]{2}{*}{$\begin{array}{l}\text { Percentage } \\
\text { inhibition of } \\
\text { adhesion }\end{array}$} \\
\hline & & & $\begin{array}{l}\text { intracellular } \\
\text { organisms }\end{array}$ & $\begin{array}{l}\text { total intracellular } \\
\text { and extracellular } \\
\text { organisms }\end{array}$ & & \\
\hline \multirow[t]{2}{*}{1} & \multirow[t]{2}{*}{$1.59 \times 10^{7}$} & \multirow{2}{*}{$\begin{array}{l}\text { NRS } \\
(200) \\
\text { ABS } \\
(200)\end{array}$} & $0.42( \pm 0.007)$ & $9 \cdot 57( \pm 0 \cdot 146)$ & \multirow{2}{*}{$\begin{array}{c}31.0 \\
(p<0.01)\end{array}$} & \multirow{2}{*}{$\begin{array}{c}46.4 \\
(p<0 \cdot 01)\end{array}$} \\
\hline & & & $0.293( \pm 0.001)$ & $5 \cdot 13( \pm 0 \cdot 088)$ & & \\
\hline \multirow[t]{2}{*}{2} & \multirow[t]{2}{*}{$1.57 \times 10^{7}$} & \multirow{2}{*}{$\begin{array}{l}\text { NRS } \\
(200) \\
\text { ALS } \\
(200)\end{array}$} & $0.289( \pm 0.01)$ & $7 \cdot 58( \pm 0 \cdot 192)$ & \multirow{2}{*}{$\begin{array}{c}89 \cdot 24 \\
(p<0 \cdot 005)\end{array}$} & \multirow{2}{*}{$\begin{array}{c}89.31 \\
(p<0.005)\end{array}$} \\
\hline & & & $0.031( \pm 0.001)$ & $0.81( \pm 0.028)$ & & \\
\hline \multirow[t]{2}{*}{3} & \multirow[t]{2}{*}{$2.0 \times 10^{8}$} & \multirow{2}{*}{$\begin{array}{l}\text { NRS } \\
(200) \\
\text { ALS } \\
(200)\end{array}$} & $2.37( \pm 0.298)$ & $43.9( \pm 1.88)$ & \multirow[b]{2}{*}{$\begin{array}{l}17 \cdot 7 \\
\text { (NS) }\end{array}$} & \multirow[b]{2}{*}{ No reduction } \\
\hline & & & $1.963( \pm 0.043)$ & $48 \cdot 8( \pm 2 \cdot 86)$ & & \\
\hline \multirow[t]{2}{*}{4} & \multirow[t]{2}{*}{$2.05 \times 10^{9}$} & \multirow{2}{*}{$\begin{array}{l}\text { NRS } \\
(200) \\
\text { ABS } \\
(200)\end{array}$} & $6 \cdot 47( \pm 0 \cdot 16)$ & $34 \cdot 8( \pm 1 \cdot 11)$ & \multirow[b]{2}{*}{ No reduction } & \multirow[b]{2}{*}{ No reduction } \\
\hline & & & $9 \cdot 75( \pm 0.382)$ & $57 \cdot 2( \pm 1 \cdot 51)$ & & \\
\hline
\end{tabular}

NS = not significant; NRS $=$ Normal Rabbit Serum; ABS, ALS—see Methods. ${ }^{*}$ See table II.

TABLE V

Effect of LPS on adhesion and invasion of HeLa cells by S. flexneri

\begin{tabular}{|c|c|c|c|c|c|c|}
\hline \multirow[b]{2}{*}{$\begin{array}{l}\text { Test } \\
\text { no. }\end{array}$} & \multirow[b]{2}{*}{$\begin{array}{c}\text { Inoculum per } \\
\text { monolayer } \\
\left(10^{7} \text { organisms }\right)\end{array}$} & \multirow[b]{2}{*}{ LPS } & \multicolumn{2}{|c|}{ Mean count* $\left(10^{6} \mathrm{cfu} /\right.$ plate $)$} & \multirow{2}{*}{$\begin{array}{c}\text { Percentage } \\
\text { reduction in } \\
\text { intracellular } \\
\text { organisms }\end{array}$} & \multirow[b]{2}{*}{$\begin{array}{l}\text { Percentage } \\
\text { inhibition } \\
\text { of adhesion }\end{array}$} \\
\hline & & & $\begin{array}{l}\text { intracellular } \\
\text { organisms }\end{array}$ & $\begin{array}{l}\text { total intracellular and } \\
\text { extracellular } \\
\text { organisms }\end{array}$ & & \\
\hline \multirow{3}{*}{1} & \multirow{2}{*}{0.94} & $\begin{array}{l}\text { E. coli } \\
(1 \mathrm{mg} / \mathrm{ml})\end{array}$ & $0.77( \pm 0.02)$ & $16 \cdot 0( \pm 1 \cdot 2)$ & \multirow{3}{*}{$\begin{array}{l}2.99 \\
\text { (NS) }\end{array}$} & \multirow{3}{*}{$\begin{array}{l}6 \cdot 25 \\
\text { (NS) }\end{array}$} \\
\hline & & $\begin{array}{l}\text { S. flexneri } \\
(1 \mathrm{mg} / \mathrm{ml})\end{array}$ & $0.747( \pm 0.016)$ & $15.0( \pm 0.75)$ & & \\
\hline & \multirow{3}{*}{1.56} & none & ND & $36 \cdot 0( \pm 0 \cdot 19)$ & & \\
\hline \multirow[t]{2}{*}{2} & & $\begin{array}{l}\text { E. coli } \\
(1 \mathrm{mg} / \mathrm{ml})\end{array}$ & ND & $38.4( \pm 0.21)$ & & No reduction \\
\hline & & $\begin{array}{l}\text { S. flexneri } \\
(1 \mathrm{mg} / \mathrm{ml})\end{array}$ & ND & $35 \cdot 1( \pm 0 \cdot 2)$ & & $\begin{array}{l}2 \cdot 5 \\
\text { (NS) }\end{array}$ \\
\hline \multirow[b]{2}{*}{3} & & none & ND & $92.0( \pm 0.73)$ & & \\
\hline & $5 \cdot 12$ & $\begin{array}{l}\text { S. flexneri } \\
(100 \mu \mathrm{g} / \mathrm{ml})\end{array}$ & ND & $87.5( \pm 0.284)$ & & $\begin{array}{l}4.9 \\
\text { (NS) }\end{array}$ \\
\hline
\end{tabular}

$\mathrm{ND}=$ not done; $\mathrm{NS}=$ not significant. $*$ See table II. 
that could block adhesion and invasion effectively when the inoculum contained $c .10^{7}$ shigellae could not do so when the inoculum size was raised to c. $2 \times 10^{8}$ cells (table IV).

\section{Effect of homologous LPS on adhesion and invasion of HeLa cells by S. flexneri}

HeLa cell monolayers were incubated with $1.56 \times 10^{7}$ and $5.12 \times 10^{7}$ cells of the test strain of $S$. flexneri in the presence of its LPS at concentrations of $100 \mu \mathrm{g} / \mathrm{ml}$ and 1.0 $\mathrm{mg} / \mathrm{ml}$. As controls, similar monolayers were set up with $E$. coli LPS at $1.0 \mathrm{mg} / \mathrm{ml}$ and with Dulbecco's medium containing no LPS. LPS did not block adhesion or invasion (table V).

\section{Discussion}

These blockade studies were designed as a simple attempt to categorise the antigens of $S$. flexneri involved in epithelial cell invasion. Since ALS was raised against live $S$. flexneri, it is expected to contain antibodies against multiple surface components, some or all of which may be involved in the process of invasion. ABS is an antiserum against heat-stable antigens. ALAS was prepared by absorbing ALS exhaustively to remove antibodies against heat-stable surface antigens. The completeness of the absorption is illustrated by the fall of the anti-LPS titre to zero. Hence for practical purposes, and with some obvious reservations, ALAS can be considered as an antiserum against heat-labile antigens.

ALS and ABS reduced the total number of intracellular shigellae by $c .31-89 \%$. This reduction was always accompanied by reduction of the same order in the numbers of shigellae adherent to the monolayers. This indicates that the reduction in invasion is a direct result of reduction in the adhesion of the shigellae to the monolayers. Control experiments at this point seemed to exclude agglutination and clumping of bacteria by the test sera as an alternative explanation for these findings.

Because ABS blocked adhesion and invasion, it was expected that ALS would lose its blocking activity after absorption with boiled cells. Surprisingly, ALAS also blocked adhesion and invasion at dilutions of 20 and 50 though not at 200. This strongly suggests that the adhesion of shigellae to the HeLa cells is mediated by heat-labile surface antigens.

There are two possible explanations for these apparently contradictory results: (1) both heat-labile and heat-stable surface antigens of $S$. flexneri may participate in adhesion; or (2) the adhesion may be mediated by heat-labile surface antigens whilst the observed blockade by ABS could reflect steric hindrance by heat-stable surface antigens that have no role in the adhesion of shigellae to HeLa cells. Because the predominant heat-stable surface antigen is LPS, its role in adhesion was investigated and ruled out.

The importance of heat-labile surface antigens in shigella adhesion and invasion has been demonstrated in another system by Adamus et al. (1980). Guinea pigs and rabbits immunised with outer membrane proteins (OMP) of $S$. flexneri were protected against experimentally induced keratoconjunctivitis whereas those immunised with heat-killed $S$. flexneri were not.

In similar studies to ours, Hale and Bonventre (1979) found that antiserum against boiled cells did not block invasion of Henle intestinal epithelial cells by shigellae. 
These results clearly contradict ours. It is likely that this is an inoculum effect; at the bacterial concentrations used by Hale and Bonventre, the blocking activity of the antiserum is likely to be saturated. When the size of the inoculum per monolayer was increased, the blocking activity of ABS was not observed in our studies.

We conclude from our present evidence that adhesion is an important step in the process of invasion of epithelial cells by shigellae and it is likely to be achieved through heat-labile surface antigens such as proteins. Heat-stable surface antigens such as LPS do not seem to be important in this phase of invasion.

\section{REFERENCES}

Adamus, G., MulczyK, M., Witkowska, D. And RomanowsKa, E. 1980. Protection against keratoconjunctivitis shigellosa induced by immunization with outer membrane proteins of Shigella spp. Infection and Immunity, 30, 321-324.

BanCROFT, H. 1957. Introduction to Biostatistics, Harper and Row, New York, p. 172.

EDWARDS, P. R. AND EwING, W. H. 1972. Identification of Enterobacteriaceae, 3rd ed., Burgess Publishing Company, Minneapolis, p. 123.

Hale, T. L. AND BonVENTRE, P. F. 1979. Shigella infection of Henle intestinal epithelial cells: role of the bacterium. Infection and Immunity, 24, 879-886.

Hale, T. L., Morris, R. E. AND Bonventre, P. F. 1979. Shigella infection of Henle intestinal epithelial cells: role of the host cell. Infection and Immunity, 24, 887-894.

KWAPINSKI, J. B. G. 1972. Methology of Immunochemical and Immunological Research, Wiley Interscience, New York, p. 404.

Labrec, E. H., Schneider, H., Magnani, T. J. and Formal, S. B. 1964. Epithelial cell penetration as an essential step in the pathogenesis of bacillary dysentery. Journal of Bacteriology, 88, 1503-1518.

MACKel, D. C., LANGLey, L. F. AND VENiCE, L. A. 1961. Use of the guinea pig conjunctivae as an experimental model for the study of virulence of Shigella organisms. American Journal of Hygiene, 73, 219-223.

Okamura, N. AND NaKaYA, R. 1977. Rough mutant of Shigella flexneri 2a that penetrates tissue culture cells but does not evoke keratoconjunctivitis in guinea pigs. Infection and Immunity, 17, 4-8.

Williams, C. A. AND Chase, M. W. 1977. Methods in Immunology and Immunochemistry, Academic Press, New York, vol. IV, p. 84. 